\title{
PERMODELAN PEMBEBANAN AKIBAT BEBAN IMPACT PADA PELEK MOBIL DENGAN SISTEM GETARAN DUA DERAJAD KEBEBASAN
}

\author{
Ragil Sukarno \\ Jurusan Teknik Mesin, Fakultas Teknik - Universitas Negeri Jakarta \\ Email : ragil.sukarno01@yahoo.com
}

\begin{abstract}
Abstrak
Dalam industri manufaktu, $r$ khususnya pada bidang otomotif Penelitian dan Pengembangan (R\&D) adalah proses yang berkelanjutan dan harus dilakukan secara tepat, supaya tidak tertinggal dalam persaingan yang sangat ketat seperti sekarang ini. Desain pelek mobil adalah kombinasi dari keindahan dan kekuatan sehingga selain desain yang menarik kekuatan juga menjadi faktor yang harus dipertimbangkan. Dalam merancang sebuah pelek mobil kita tidak bisa mengabaikan faktor dari ban, sehingga pelek dan ban adalah sebuah kesatuan dalam sebuah roda. Roda mobil mengalami berbagai macam pembebanan, dan diantara beban-beban yang ada, beban yang diakibatkan oleh impact memegang peranan yang paling besar. Dalam mensimulasikan beban akibat impact ini akan sangat sulit bila menggunakan analisa statis jika tidak dimodelkan terlebih dahulu sebagai sebuah beban tunggal. Dan dalam penelitian ini pembebanan akibat beban impact dimodelkan sebagai sistem getaran dua derajad kebebasan. Metode penelitian ini diawali dengan memasukkan suspensi dan ban dimasukkan dalam permodelan. Data yang didapatkan dari permodelan sistem getaran ini kemudian disimulasikan dengan menggunakan Software Metode Elemen Hingga. Hasil permodelan dengan sistem getaran dua derajad kebebasan dan software metode elemen hingga didapatkan bahwa pada pelek jenis baja press, titik lokasi yang paling kritis adalah pada daerah hat radius. Ketebalan pelek juga berpengaruh terhadap besarnya tegangan impact, dimana semakin tebal dimensi pelek maka tegangan akibat beban impact juga semakin kecil. Dan ini tentunya juga akan berpengaruh secara keseluruhan terhadap faktor keamanan dari pelek dan roda mobil bahwa faktor keamanan akan meningkat seiring dengan meningkatnya ketebalan.
\end{abstract}

Kata kunci : roda mobil, getaran 2 derajad kebebasan, metode elemen hingga

\section{PENDAHULUAN}

Dalam industri manufaktur khususnya pada bidang otomotif Penelitian dan Pengembangan (R\&D) adalah proses yang berkelanjutan dan harus dilakukan secara tepat, supaya tidak tertinggal dalam persaingan yang sangat ketat seperti sekarang ini. Desain yang cantik dan menarik adalah hal pertama yang akan dilihat oleh pelanggan dari sebuah produk. Sehingga tahapan dalam proses desain ini memegang peranan yang sangat besar yang akan menentukan produk yang akan kita hasilkan nanti diterima atau tidak oleh pelanggan. Desain pelek mobil adalah kombinasi dari keindahan dan kekuatan sehingga selain desain yang menarik kekuatan juga menjadi faktor yang harus dipertimbangkan. Dalam merancang sebuah pelek mobil kita tidak bisa mengabaikan faktor dari ban, sehingga pelek dan ban adalah sebuah kesatuan dalam sebuah roda. Roda mobil mengalami berbagai macam pembebanan, dan ini harus dianalisa satu persatu untuk melihat kekuatan dari desain yang kita rancang. Diantara beban-beban yang ada, beban yang diakibatkan oleh impact memegang peranan yang paling besar, dan dalam penelitian ini akan difokuskan pada pembebanan impact.

Untuk mengetahui kekuatan dari pelek dalam menahan beban biasanya dilakukan melalui pengujian laboratorium, misalnya melalui uji impact atau uji fatig. Tapi metode ini memerlukan biaya yang sangat mahal. Metode lain yang dapat dilakukan untuk mengetahui kekuatan dari kedua jenis pelek tersebut adalah melalui metode analisa tegangan dengan menggunakan software metode elemen hingga. 


\section{TUJUAN PENELITIAN}

Tujuan dari penelitian ini adalah untuk menghasilan permodelan pembebanan pada roda mobil akibat beban impact, sehingga hasil penelitian ini bisa menjadi acuan yang bisa diterapkan dalam analisa tegangan atau analisa struktur dengan menggunakan software metode elemen hingga. Dan diharapkan metode ini bisa bermanfaat untuk menyelesaikan kasus-kasus tentang beban impact di bidang perancangan roda atau yang lain.

\section{METODE PENELITIAN}

Pada penelitian ini akan dilakukan permodelan pelek dan ban sebagai satu kesatuan sebagai sebuah roda dalam sistem getaran dua derajad kebebasan. Permodelan ini dilakukan secara manual dan hasil dari permodelan ini disimulasikan dan dianalisa kekuatan statisnya dengan menggunakan software Metode Elemen Hingga. Metode penelitian yang digunakan dalam penelitian ini dapat dilihat pada gambar 1 .

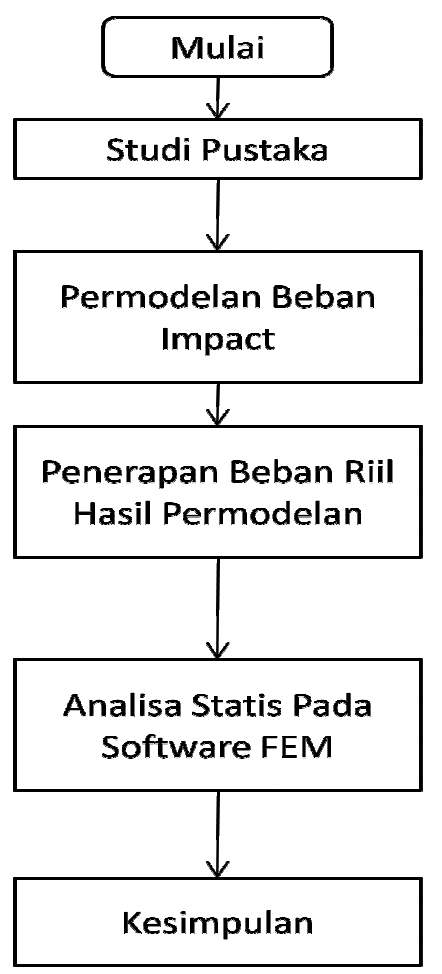

Gambar 1. Diagram Alir Metode Penelitian

\section{PEMBEBANAN IMPACT PADA RODA MOBIL}

Roda mobil terdiri dari ban dan pelek. Dan pada kendaraan, ban roda ini juga terhubung dengan pegas suspensi atau pegas yang bekerja bersama-sama untuk memberikan kenyamanan pada penumpang. Fungsi dari pegas ini selain untuk memberikan kenyamanan pada penumpang, juga berfungsi untuk meredam beban kejut atau impact pada kendaraan. Sehingga dalam desain sebuah pelek, permodelan suspensi sebagai satu kesatuan bersama ban dan pelek mutlak harus dilakukan.

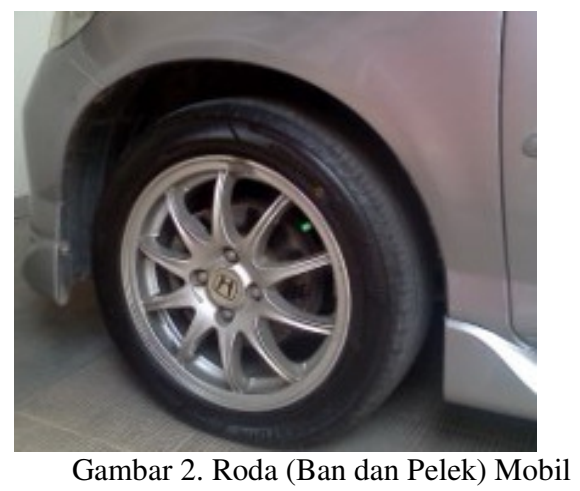

Ciri-ciri dari beban impact adalah gayagaya yang terjadi sangat besar dan berlangsung dalam waktu yang sangat singkat. Gaya impact akan menimbulakan gaya dan deflkesi yang lebih besar dari beban statis. Pada pemodelan impact ini diasumsikan kendaraan jatuh pada ketinggian tertentu, dan dalam perhitungan beban impact ini tinggi jatuh kendaraan adalah sebesar jari-jari ban. Untuk mencari besarnya gaya akibat impact (tumbukan) pada setiap pelek akibat jatuh bebas dapat dimodelkan sebagai sistem getaran dua derajad kebebasan seperti pada gambar 3 . Permodelan dilakukan pada masing-masing satu roda. Untuk permodelan adalah sama metodenya, dan hasil dari masing-masing beban impact untuk tiap-tiap roda akan berbeda tergantung dari distribusi beban pada masing-masing roda.

Dari gambar 3, terlihat massa 1 adalah 1/4 dari massa mobil. Kekakuan pegas, k1 adalah kekakuan dari pegas suspensi kendaraan. Massa 2, m2 adalah massa dari pelek dan $\mathrm{k} 2$ adalah kekakuan dari ban. 


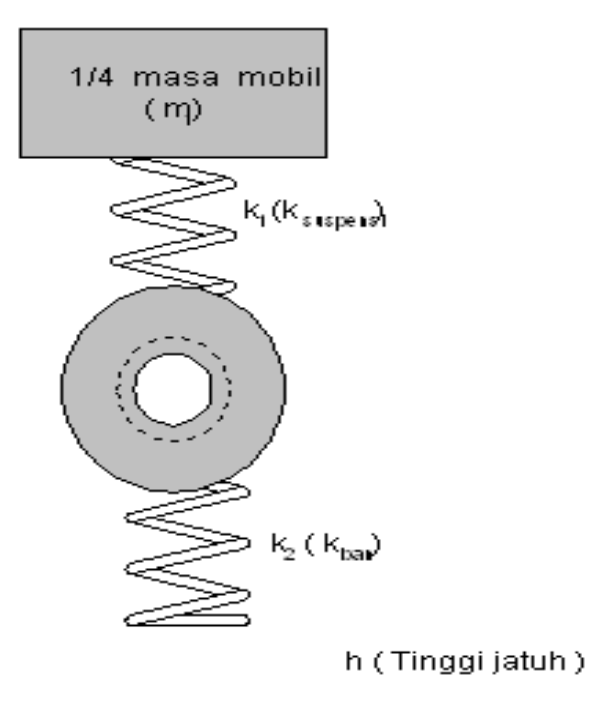

Gambar 3. Permodelan Sistem Getaran

Dua derajad Kebebasan pada Mobil

Dari permodelan pada gambar 3, bisa digambarkan diagram benda bebas sebagai berikut
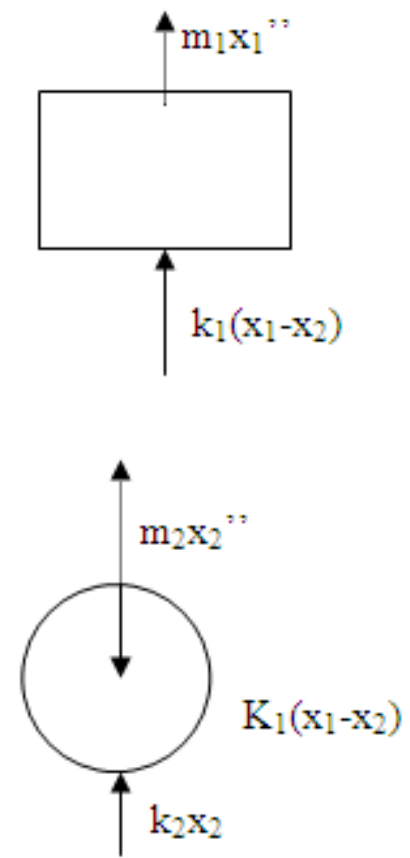

Gambar 4 . Diagram Benda Bebas Sistem Getaran Dua Derajad Kebebasan

Dari diagram benda bebas diatas dapat diturunkan persamaan gerak sebagai berikut:

$\mathrm{m}_{1} \mathrm{x}_{1}{ }^{\prime}+\mathrm{k}_{1}\left(\mathrm{x}_{1}-\mathrm{x}_{2}\right)=0$, atau

(Pers. 1) $\mathrm{m}_{1} \mathrm{x}_{1}{ }^{\prime}+\mathrm{k}_{1} \mathrm{x}_{1}-\mathrm{k}_{1} \mathrm{x}_{2}=0$

(Pers. 2)

$\mathrm{m}_{2} \mathrm{x}_{2}{ }^{\prime}{ }^{\prime}+\mathrm{k}_{2} \mathrm{x}_{2}-\mathrm{k}_{1}\left(\mathrm{x}_{1}-\mathrm{x}_{2}\right)=0$, atau

(Pers. 3)

$\mathrm{m}_{2} \mathrm{x}_{2}{ }^{\prime}+\mathrm{k}_{2} \mathrm{x}_{2}+\mathrm{k}_{1} \mathrm{x}_{2}-\mathrm{k}_{1} \mathrm{x}_{1}=0$

(Pers. 4)

dimana:

$\mathrm{x}_{1}=\mathrm{X}_{1} \sin \omega \mathrm{t}$

$\mathrm{x} 1^{\prime}=\omega \mathrm{X} 1 \cos \omega \mathrm{t}$

$\mathrm{x}_{1} "=-\omega^{2} \mathrm{X}_{1} \sin \omega \mathrm{t}$

dan

$\mathrm{x}_{2}=\mathrm{X}_{2} \sin \omega \mathrm{t}$

$\mathrm{x}_{2}{ }^{\prime}=\omega \mathrm{X}_{1} \cos \omega \mathrm{t}$

$\mathrm{x}_{2},=-\omega^{2} \mathrm{X}_{1} \sin \omega \mathrm{t}$

Dengan mensubsitusikan persamaan diatas ke persamaan 2 dan 4 , dan didapatkan sebagai berikut

$\left(\mathrm{k}_{1}-\mathrm{m}_{1} \omega^{2}\right) \mathrm{X}_{1}-\mathrm{k}_{1} \mathrm{X}_{2}=0$

(Pers. 5)

$\left(\mathrm{k}_{1}+\mathrm{k}_{2}-\mathrm{m}_{2} \omega^{2}\right) \mathrm{X}_{2}-\mathrm{k}_{1} \mathrm{X}_{1}=0$

(Pers. 6)

Dari persamaan 5 dan 6 dapat ditentukan fraksi modal, yaitu

$\chi=\frac{X_{2}}{X_{1}}=\frac{k_{1}-m_{1} \omega^{2}}{k_{1}}=\frac{k_{1}}{k_{1}+k_{2}-m_{2} \omega^{2}}$ (Pers.

7)

dengan melakukan perkalian silang pada persamaan 7 didapat persamaan frekuensi sebagai berikut :

$\left(\mathrm{k}_{1}-\mathrm{m}_{1} \omega^{2}\right)\left(\mathrm{k}_{1}+\mathrm{k}_{2}-\mathrm{m}_{2} \omega^{2}\right)-\mathrm{k}_{1}{ }^{2}=0 \quad$ (Pers. 8$)$

$\mathrm{k}_{1}^{2}-\mathrm{k}_{1} \mathrm{~m}_{1} \omega^{2}+\mathrm{k}_{1} \mathrm{k}_{2}-\mathrm{k}_{2} \mathrm{~m}_{1} \omega^{2}-\mathrm{k}_{1} \mathrm{~m}_{2} \omega^{2}+$ $\mathrm{m}_{1} \mathrm{~m}_{2} \omega^{4}-\mathrm{k}_{1}^{2}=0$

(Pers. 9)

$\mathrm{m}_{1} \mathrm{~m}_{2} \omega^{4}-\omega^{2}\left(\mathrm{k}_{1} \mathrm{~m}_{1}+\mathrm{k}_{1} \mathrm{~m}_{2}+\mathrm{k}_{2} \mathrm{~m}_{1}\right)+\mathrm{k}_{1} \mathrm{k}_{2}=0$

(Pers. 10) 


$$
\omega^{4}-\frac{\left(\left(m_{1}+m_{2}\right) k_{1}+k_{2} m_{1}\right)}{m_{1} m_{2}} \omega^{2}+\frac{k_{1} k_{2}}{m_{1} m_{2}}=0
$$

(Pers. 11)

Untuk mencari frekuensi pribadi dari sistem dapat dilakukan dengan memasukkan harga-harga spesifikasi yang didapatkan dari data kendaraan dan data komponen sebagai berikut

\section{Asumsi :}

- $\mathrm{ml}=550 \mathrm{~kg}=5396 \mathrm{~N}$

- $\mathrm{k} 1=27000$

- $\mathrm{m} 2=40 \mathrm{~kg}=392.4 \mathrm{~N}$

- $\mathrm{k} 2=270000 \mathrm{~N} / \mathrm{m}$

Dengan memasukkan data-data diatas, kedalam persamaan 11 sebagai berikut :

$$
\begin{aligned}
\omega^{4}-761.88 \omega^{2}+3442.9 & =0 \\
\omega_{1}{ }^{2} & =757.34 \\
\omega_{2}{ }^{2} & =4.54
\end{aligned}
$$

untuk $\omega_{1}^{2}=757.34$, fraksi modal adalah

$$
\chi=\frac{X_{2}}{X_{1}}=-150.35
$$

untuk $\omega_{2}^{2}=4.54$, fraksi modal adalah

$$
\chi=\frac{X_{2}}{X_{1}}=0.093
$$

Dengan diketahuinya fraksi modal, maka kita bisa dapatkan persamaan gerak sebagai berikut:

$$
\begin{aligned}
& \left\{\begin{array}{l}
x 1 \\
x 2
\end{array}\right\}=\left\{\begin{array}{c}
1 \\
-150.35
\end{array}\right\}\left(A_{1} \cos \omega_{1} t+B_{1} \operatorname{Sin} \omega_{1} t\right)+ \\
& \left\{\begin{array}{c}
1 \\
0.093
\end{array}\right\}\left(A_{2} \cos \omega_{2} t+B_{2} \operatorname{Sin} \omega_{2} t\right) \ldots \ldots(\text { Pers. }
\end{aligned}
$$

12)

$$
\begin{aligned}
& \left.\begin{array}{l}
x 1^{\prime} \\
x 2^{\prime}
\end{array}\right\}=\left\{\begin{array}{c}
1 \\
-150.35
\end{array}\right\}\left(-\mathrm{A}_{1} \omega_{1} \text { Sin } \omega_{1} \mathrm{t}+\mathrm{B}_{1} \omega_{1}\right. \\
& \left.\operatorname{Cos} \omega_{1} \mathrm{t}\right)+\left\{\begin{array}{c}
1 \\
0.093
\end{array}\right\}\left(\begin{array}{ll}
-\mathrm{A}_{2} \omega_{2} & \text { Sin } \omega_{2} \mathrm{t}+\mathrm{B}_{2} \omega_{2}
\end{array}\right. \\
& \left.\operatorname{Cos} \omega_{2} \mathrm{t}\right) .
\end{aligned}
$$

Dengan memasukkan kondisi kondisi awal:

$\mathrm{X} 1(0)=0$ dan $\mathrm{X} 2(0)=0$, maka

$$
\begin{aligned}
& \left\{\begin{array}{l}
0 \\
0
\end{array}\right\}=\left\{\begin{array}{c}
1 \\
-150.35
\end{array}\right\}\left(\mathrm{A}_{1} \cos \omega_{1} 0+\mathrm{B}_{1} \operatorname{Sin} \omega_{1} 0\right) \\
& +\left\{\begin{array}{c}
1 \\
0.093
\end{array}\right\}\left(\mathrm{A}_{2} \cos \omega_{2} 0+\mathrm{B}_{2} \operatorname{Sin} \omega_{2} 0\right) \\
& \left\{\begin{array}{l}
0 \\
0
\end{array}\right\}=\left\{\begin{array}{c}
1 \\
-150.35
\end{array}\right\}\left(\mathrm{A}_{1}\right)+\left\{\begin{array}{c}
1 \\
0.093
\end{array}\right\}\left(\mathrm{A}_{2}\right)
\end{aligned}
$$$$
\text { sehingga } \mathrm{A} 1=\mathrm{A} 2=0
$$$$
\text { untuk X1' }(0)=\mathrm{v} \quad \text { dan } \mathrm{X} 2^{\prime}(0)=\mathrm{v}
$$$$
\left\{\begin{array}{l}
v \\
v
\end{array}\right\}=\left\{\begin{array}{c}
1 \\
-150.35
\end{array}\right\}\left(-\mathrm{A}_{1} \omega_{1} \operatorname{Sin} \omega_{1} 0+\mathrm{B}_{1} \omega_{1} \operatorname{Cos} \omega_{1} 0\right)
$$$$
+\left\{\begin{array}{c}
1 \\
0.093
\end{array}\right\}\left(-\mathrm{A}_{2} \omega_{2} \operatorname{Sin} \omega_{2} 0+\mathrm{B}_{2} \omega_{2} \operatorname{Cos} \omega_{2} 0\right)
$$$$
\left\{\begin{array}{l}
v \\
v
\end{array}\right\}=\left\{\begin{array}{c}
1 \\
-150.35
\end{array}\right\}\left(\mathrm{B}_{1} \omega_{1}\right)+\left\{\begin{array}{c}
1 \\
0.093
\end{array}\right\}\left(\mathrm{B}_{2} \omega_{2}\right)
$$

$$
\begin{aligned}
& \mathrm{v}=\left(\mathrm{B}_{1} \omega_{1}\right)+\left(\mathrm{B}_{2} \omega_{2}\right) \\
& \mathrm{v}=-150.35\left(\mathrm{~B}_{1} \omega_{1}\right)+0.093\left(\mathrm{~B}_{2} \omega_{2}\right)
\end{aligned}
$$

didapatkan :

$$
\begin{aligned}
& \left(\mathrm{B}_{1} \omega_{1}\right)=-0.01 ; \\
& \mathrm{B} 1=-0.00036, \text { dan } \omega 1=27.52 \\
& \left(\mathrm{~B}_{2} \omega_{2}\right)=2.46 ; \\
& \mathrm{B} 2=1.15 ; \text { dan } \omega 2=2.13
\end{aligned}
$$


sehingga persamaan gerak menjadi sebagai berikut

$X 1=B_{1} \operatorname{Sin} \omega_{1} t+B_{2} \operatorname{Sin} \omega_{2} t$

( Pers. 14)

$X 2=-150.35 B_{1} \operatorname{Sin} \omega_{1} t+0.093 B_{2} \operatorname{Sin} \omega_{2} t$

(Pers. 15)

Dan dengan memasukkan nilai B1, $\omega 1$, B2, dan $\omega 2$ kedalam persamaan 14 dan 15 , kita bisa mendapatkan persamaan gerak sebagai berikut

$X_{1}=-0.00036 \operatorname{Sin}(27.52 . t)+1.15 \operatorname{Sin}(2.13 . t)$

(Pers.16)

$X_{2}=0.054 \operatorname{Sin}(27.52 . t)+0.107 \operatorname{Sin}(2.13 . t)$

(Pers. 17)

Dengan menggunakan persamaan 16 dan 17, kita bisa menggambarkan pada sebuah grafik hubungan simpangan terhadap waktu akibat peristiwa impact, seperti ditunjukkan pada gambar 5

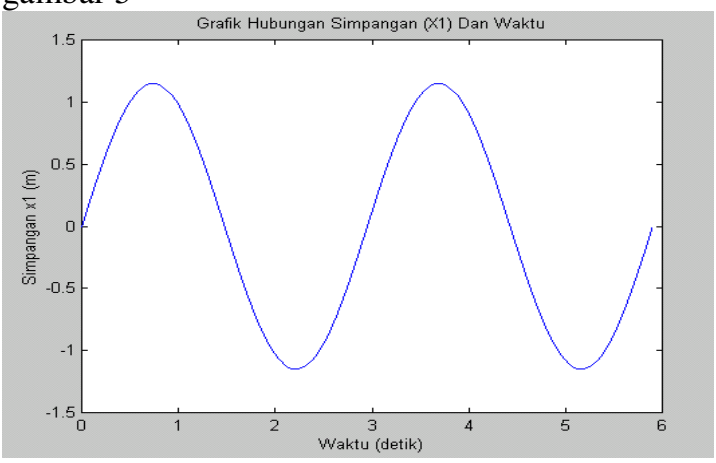

(a).Hubungan Simpangan(x1) dan Waktu ;

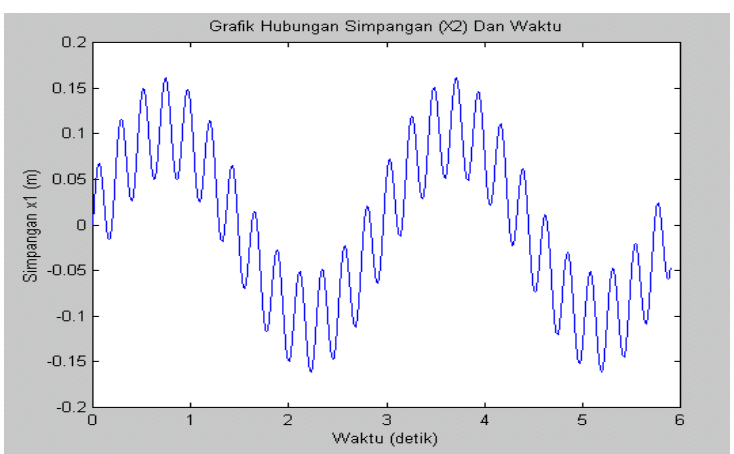

(b) Hubungan Simpangan (x2) dan Waktu

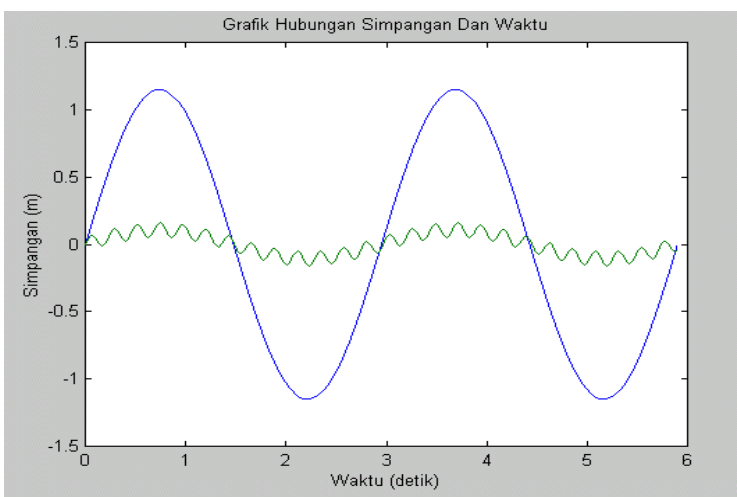

(c) Hubungan simpangan (x1 dan $\mathrm{x} 2$ ) Terhadap Waktu.

Gambar 5. Grafik Hubungan Simpangan dan Waktu Akibat Impact

Sehingga besarnya gaya impact yang (4 $35 \mathrm{j}^{3} \mathrm{a}$ di dapat dihitung dengan menggunakan persamaan 18 ( dari diagram benda bebas) berikut ini adalah

$$
\mathrm{F}=\mathrm{k}_{2} \mathrm{X}_{2}-\mathrm{k}_{1}\left(\mathrm{x}_{1}-\mathrm{X}_{2}\right) \quad(\text { Pers. 18) }
$$

Hubungan besarnya gaya impact terhadap waktu dapat ditunjukkan pada gambar 6 .

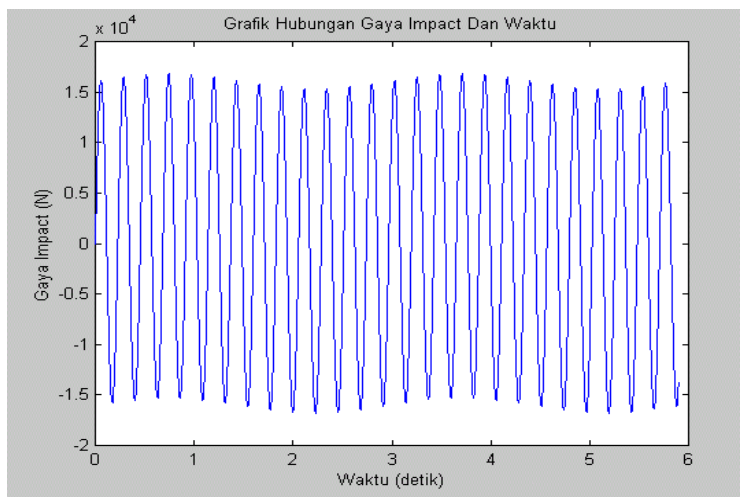

Gambar 6 Grafik Hubungan Gaya Impact Dan

Waktu

Dan dari gambar 5, dapat dilihat besarnya gaya impact maksimum adalah 16136.229 $\mathrm{N}$ atau $1644.876 \mathrm{~kg}$. 


\section{SIMULASI PEMBEBANAN BEBAN IMPACT DENGAN METODE ELEMEN HINGGA}

\subsection{Penentuan Beban Impact}

Pada kondisi sebenarnya pada saat mengalami beban impact, roda akan mengalami beban gabungan yang terdiri dari beban karena tekanan ban, gaya berat gravitasi, gaya sentrifugal, gaya berat kendaraan, gaya traksi dan beban impact.

a. Tekanan ban (besarnya $172.000 \mathrm{~N} / \mathrm{m}^{2}$ )

b. Gaya Gravitasi ( Masukkan density, 7860 $\mathrm{kg} / \mathrm{m}^{3}$ untuk material baja dan $2710 \mathrm{~kg} / \mathrm{m}^{3}$ untuk material alumunium alloy dan percepatan gravitasi , $g=9,81 \mathrm{~m} / \mathrm{s}^{2}$ )

c. Gaya sentrifugal (Masukkan density, pusat graviatsi dan putaran rps (putaran per second). Besarnya putaran adalah sebesar $20 \mathrm{~m} / \mathrm{s}$.)

d. Gaya berat kendaraan (Berat kendaraan pada masing-masing roda belakang adalah $5396 \mathrm{~N})$

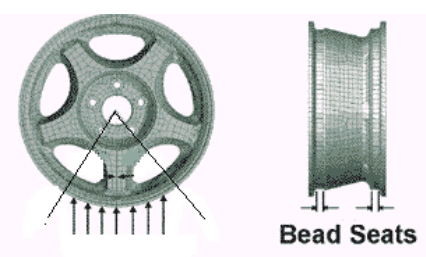

Gambar 7. Pemodelan Gaya Berat

e. Gaya traksi ( besarnya $395.9 \mathrm{~kg}$ atau 3884 N)

f. Gaya impact Untuk pemodelan gaya impact, gaya dianggap sebagai Gaya Per Area dan ditempatkan pada surface bead seats. Pemodelan adalah sama dengan pemodelan gaya berat kendaraan, hanya besarnya impact adalah $16136.229 \mathrm{~N}$ atau $1644.876 \mathrm{~kg}$ dan sudut kontaknya adalah $67.5^{\circ}$

Jadi jumlah pembebanan karena impact adalah total dari gaya-gaya tersebut diatas

\subsection{Menentukan Tumpuan (Constrain)}

Setelah proses pembebanan selesai, maka langkah selanjutnya adalah menentukan tumpuan atau constrain. Pada pemodelan pelek ini, constrain diletakkan pada surface lubang baut dengan cara difixed.

\subsection{Melakukan Analisa Statik dengan Software Metode Elemen Hingga}

Untuk melihat hasil permodelan beban impact, maka hasil perhitungan beban disimulasi terhadap kondisi desain pelek yang kita rancang dengan menggunakan software Metode Elemen Hingga. Simulasi dilakukan dengan mengatur berbagai ketebalan dan pembebanan impact pada pelek. Beberapa parameter yang digunakan dalam analisa kekuatan statis pada software Metode Elemen Hingga adalah sebagai berikut:

a. Penggambaran Pelek dilakukan dengan program dan di export ke dalam format ACIS, sehingga bisa langsung digunakan dalam program Metode Elemen Hingga.

b. Menggunakan Model Pelek Baja Press dengan berbagai ketebalan dan desain model sebagai model simulasi (ukuran 5 J 13, dengan ketebalan rim $3 \mathrm{~mm}$, dan ketebalan piringan 2,3, dan $5 \mathrm{~mm}$.

- Pelek 5 J 13 artinya Lebar pelek 5 inchi , Diameter 13 inchi, J melambangkan jenis Flens pelek.

- Pelek 6 JJ 13 artinya Lebar pelek 6 inchi, Diameter 13 inchi, JJ melambangkan jenis Flens pelek.

6. Menentukan jenis elemen dan material, Untuk Material Pelek Baja Press, yaitu Steel High-Strength-low-alloy

- Modulus Young : $200 \mathrm{Gpa}$

- Modulus Geser : $79 \mathrm{Gpa}$

- Density : $7860 \mathrm{~kg} / \mathrm{m}^{3}$

- Ultimat strength $: 480 \mathrm{Mpa}$

- Yield strength : $350 \mathrm{Mpa}$

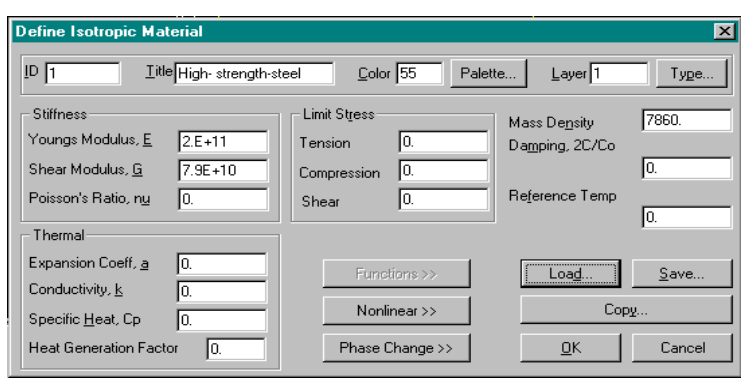

Gambar 8 Kotak Dialog Material Baja

Setelah pendefinisian material dan propertinya, maka pembuatan model selanjutnya adalah melakukan meshing elemen. Perintah ini untuk menentukan ukuran meshing dari tiap elemen yang akan dibentuk. Setelah proses meshing dilakukan maka dilanjutkan dengan proses pemeriksaan nodal dan elemen. Penggunaan Tool $>$ Check $>$ Coincident Nodes dan Tool $>$ Check $>$ Coincident Element. 


\section{HASIL DAN PEMBAHASAN}

Pemodelan pelek mobil yang dilakukan dengan menggunakan sistem getaran dua derajad kebabasan yang telah menghasilkan nilai dengan menggunakan software Metode Elemen Hingga dilakukan terhadap geometri pelek baja press dan pelek coran paduan. Untuk pelek baja press analisa akan dilakukan pada pelek dengan ketebalan piringan (disk) $2 \mathrm{~mm}, 3 \mathrm{~mm}$ dan $5 \mathrm{~mm}$.

Pelek adalah benda yang berputar (berotasi), sehingga kemungkinan terjadinya perubahan tegangan akibat posisi rotasi juga akan terjadi. Untuk itu pada analisa terhadap pelek ini akan dilakukan analisa terhadap beban berdasarkan posisi rotasi dari palek. Untuk pelek baja press rotasi akan dilakukan pada posisi 0 , $22.5,45,67.5,90,112.5,135,157.5,180,202.5$, $225,247.5,270,292.5,315,337.5$ dan 360 dan untuk palek jenis coran paduan akan dilakukan rotasi pada posisi $0,45,90,135,180,225,270,315$, dan 360 .

Pada hasil analisa pada pelek ini,akan dapat dilihat daerah-daerah kritis dari masingmasing pelek . Letak daerah kritis dari Pelek Baja press adalah seperti pada gambar 9 .

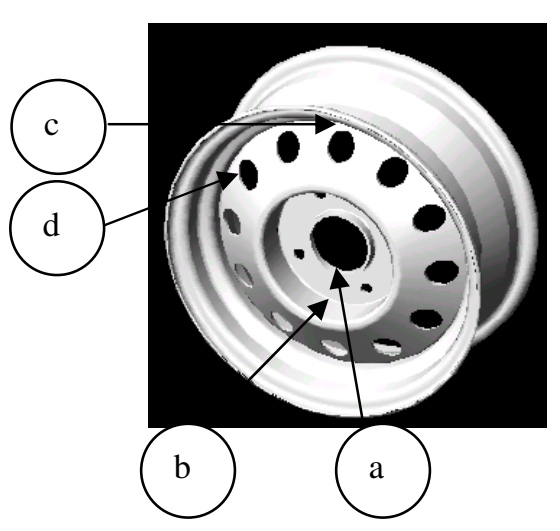
a. Hat radius,
b. Lubang baut,
c. Rim,
d. Lubang disk

Gambar 9 Posisi Daerah Kritis Pelek Baja Press

Dari hasil analisa dengan menggunakan software Metode Elemen Hingga, tegangan tegangan kritis akibat pembebanan impact pada pelek selalu muncul di lokasi yang sama dari setiap kondisi pembebanan dan rotasi posisi pelek. Pada pelek baja press, titik kritis selalu muncul pada daerah hat radius Sedangkan pada pelek coran paduan, titik kritis selalu muncul pada daerah lubang baut diperlihatkan sebagai berikut.

$$
\begin{aligned}
& \text { Pelek baja } 2 \mathbf{~ m m} \text { (Pada hat radius) } \\
& \begin{array}{ll}
\sigma_{\text {maks }} & =348.472 \mathrm{Mpa} \\
\sigma_{\min } & =58.968 \mathrm{Mpa}
\end{array}
\end{aligned}
$$

Pelek baja 3 mm (Pada hat radius)

$$
\begin{aligned}
\sigma_{\text {maks }} & =226.12 \mathrm{Mpa} \\
\sigma_{\min } & =45.624 \mathrm{Mpa}
\end{aligned}
$$

Pelek baja 5 mm (Pada hat radius)

$$
\begin{array}{ll}
\sigma_{\text {maks }} & =102.519 \mathrm{Mpa} \\
\sigma_{\min } & =31.755 \mathrm{Mpa}
\end{array}
$$

Dari data diatas, besarnya ketebalan pelek akan mempunyai banyak pengaruh dalam mendesain sebuah pelek. Pertimbangan faktor biaya, faktor kenyamanan dan faktor keamanan menjadi sesuatu yang sangat vital dalam desain sebuah pelek. Dari data diatas kita bisa memodelkan tegangan karena pembebanan impact.

\section{KESIMPULAN}

Dari analisa tegangan statis pada pelek mobil akibat pembebanan impact pada jenis pelek baja press dan pelek coran paduan, dapat diambil suatu kesimpulan sebagai berikut:

1. Pembebanan akibat beban impact bisa dimodelkan dengan menggunakan sistem getaran dua derajad kebebasan.

2. Pembebanan aktual pada kendaraan adalah merupakan beban gabungan, dan bila kita akan mensimulasikan pembebanan impact, maka beban akibat tekanan ban, gaya berat gravitasi, gaya sentrifugal, gaya berat kendaraan, gaya traksi juga harus dimasukkan.

3. Dengan memodelkan pembebanan impact dengan sistem dua derajad kebebasan, kita bisa mendapatkan nilai beban gabungan yang nilainya bisa kita pergunakan sebagai permodelan dengan menggunakan software metode elemen hingga analisa statis.

4. Daerah yang paling kritis pada pelek baja press pada hat radius dan lubang baut, sedangkan pada pelek coran paduan adalah pada daerah rim pelek.

5. Desain dan material mempunyai pengaruh yang besar terhadap kekuatan dari pelek dan ketahanan terhadap beban impact. 


\section{DAFTAR PUSTAKA}

1. Steidel, R.F, Jr., 1978, “An introduction To Mechanical Vibrations", $3^{\text {nd }}$ Edition, John Willey \& Sons, New York.

2. Popov, E.P., Zainal Astamar, 1996, "Mekanika Teknik", edisi kedua, Erlangga, Jakarta.

3. MSC, 1998, "MSC/Nastran for Windows : Analysis Examples Manual", The MacNeal-Schwendler Corporation.

4. Kraige L.G., Meriam J.L," Mekanika Teknik Statika", edisi kedua Erlangga, Jakarta,.
5. Shigley Joseph E., Mitchell Larry D., “ Perencanaan Teknik Mesin”,Erlangga, Jakarta, 1994.

6. Kragelsky, "Friction Wear Lubrication", Moscow, 1982.

7. Gillespie Thomas D.,"Fundamental of Vehicle Dynamics", Society of Automotive Engineer,1992.

8. Satrijo Djoeli, "Modul I: Dinamika Kendaraan", Universitas Diponegoro, Semarang, 1999.

9. Satrijo Djoeli, "Modul II : Dinamika Kendaraan", Universitas Diponegoro, Semarang, 1999. 